Jowita Tenderowicz

Uniwersytet Jagielloński w Krakowie e-mail: jowita.tenderowicz@doctoral.uj.edu.pl

Karolina Wiecheć

Uniwersytet Jagielloński w Krakowie e-mail: karolina.wiechec@doctoral.uj.edu.pl

\title{
ROLA PRZYWÓDCY W PIONIERSKIM PROJEKCIE CROWDFUNDINGOWYM. STUDIUM PRZYPADKU FILMU WSZYSTKO
}

\begin{abstract}
The role of the leader in the pioneering crowdfunding system: Case study of movie Everything
\end{abstract}

The subject of the research is an attempt to get to know and describe the role of a leader in the pioneering crowdfunding project Everything - the first Polish film financed by Internet users. The methods used are: case study, anthropological interview, analysis of texts and audiovisual material, non-participant observation.

Keywords: crowdfunding, crowdsourcing, movie, leader, culture

\section{Streszczenie}

Przedmiotem badań jest próba poznania i opisania roli przywódcy w pionierskim projekcie crowdfundingowym Wszystko - pierwszym polskim filmie finansowanym przez internautów. Zastosowane metody badawcze to: studium przypadku, wywiad antropologiczny, analiza tekstów i materiałów audiowizualnych oraz obserwacja nieuczestnicząca.

Słowa kluczowe: crowdfunding, crowdsourcing, film, lider, kultura

\section{Wprowadzenie}

Wszystko w reżyserii Artura Wyrzykowskiego to pierwszy polski film finansowany w dużej części przez internautów metodą crowdfundingu, i to na tym ostatnim skupiają się niniejsze badania. Warto jednak zaznaczyć, że autor filmu 
skorzystał również przy tworzeniu tej produkcji z rozwiązania, jakim jest crowdsourcing. Celem artykułu jest przedstawienie roli przywódcy w kierowaniu projektem oraz metod i technik, które wykorzystywał w twórczym działaniu pomysłodawca całego przedsięwzięcia, aby spełnić zawodowe marzenie i wyprodukować swój pierwszy film. Jego premiera odbyła się w 2009 roku. Choć nie odniósł on sukcesu komercyjnego, to jednak na zawsze pozostanie pierwszym polskim filmem, który mógł powstać dzięki nowatorskim jak na tamte czasy metodom finansowania, czyli crowdfundingowi i crowdsourcingowi.

Wszystko to krótkometrażowa produkcja, na którą internauci przekazali $28306 \mathrm{zł}$ i o której w czasie promocji można było usłyszeć w niemal wszystkich ogólnopolskich i lokalnych mediach. Film Wszystko autorki tego artykułu znają niemal od samego początku. Obserwację tej produkcji prowadziły od początku jej powstawania, od momentu zbierania funduszy przez premierę, dystrybucję, wydanie DVD po spotkanie z pomysłodawcą i twórcą, poznanie go i możliwość współpracy z nim. Nie sposób mówić w Polsce o crowdfundingu i crowdsourcingu w kulturze, nie mając na myśli właśnie Wyrzykowskiego i tego, czego dokonał, jak zapoczątkował na skalę całego kraju zbiórkę funduszy na film wśród społeczności internetowej. Co nie mniej istotne, zmobilizował społeczności lokalne do tego, aby same powiedziały, czego oczekują i gdzie chcą zobaczyć przygotowywaną przez niego produkcję.

$\mathrm{W}$ artykule jako metody badawcze wykorzystano analizę tekstów w formie materiałów internetowych, a także metody etnograficzne, czyli obserwację nieuczestniczącą i wywiad antropologiczny $z$ autorem i wykonawcą projektu zapisany w formie audiowizualnej, oraz studium przypadku.

\section{Metodyka badań}

Metody i narzędzia badawcze, które zostały użyte, aby zgłębić poddany analizie temat, należą w dużej mierze do grupy tych jakościowych. Główną podstawą rozważań zawartych $\mathrm{w}$ artykule są materiały zebrane za pomocą metod stosowanych w etnografii, a dokładniej obserwacji nieuczestniczącej oraz wywiadu antropologicznego. Są to metody polegające na dokładnym patrzeniu w przypadku obserwacji oraz słuchaniu w przypadku wywiadu. Wywiad antropologiczny według Moniki Kostery to pogłębiona rozmowa [Kostera, 2003], z kolei obserwacja nieuczestnicząca polega na przypatrywaniu się danemu zjawisku nieco z boku i pozostaniu niezwiązanym $\mathrm{w}$ żaden sposób $\mathrm{z}$ opisywanym problemem [Kostera, 2003]. Analiza tekstu oraz materiałów wideo jest nieodłącznie związana z ich interpretacją przez czytanie i oglądanie. Zostawia nam to pewną swobodę w rozumieniu tego, co mieliśmy okazję przeczytać lub zobaczyć. Interpretacja jest także swoistą parafrazą odebranych komunikatów [Brożek, 2014]. Całość zebranych materiałów badawczych została w niniejszym artykule zaprezentowana za pomocą studium przypadku.

Nie sposób pisać o metodach, technikach i roli przywódcy w projekcie bez opisania historii jego powstania. Autorki artykułu posłużyły się czterema źródłami 
przy skompletowaniu tej opowieści. Przede wszystkim wywiadem pogłębionym przeprowadzonym z Arturem Wyrzykowskim 26 maja 2013 roku. Wywiad został zarejestrowany w formie audiowizualnej, przeprowadzono go we wszystkich miejscach związanych z filmem: tam, gdzie był realizowany, gdzie miał premierę oraz w studiu postprodukcyjnym. Inną metodą badawczą była miesięczna obserwacja nieuczestnicząca przeprowadzona w 2015 roku. Ponadto wykorzystano treść pochodzącą ze strony internetowej wszystko.net oraz materiały audiowizualne dostępne w serwisie YouTube. Zebrane materiały tworzą historię człowieka, który miał wielkie marzenie i zdołał je zrealizować, choć nie było to wcale proste i wymagało wielkiego samozaparcia i odwagi.

\section{Projekt Wszystko}

Wyrzykowski, w chwili gdy idea przedsięwzięcia była już mocno zakorzeniona w jego głowie, był studentem szkoły filmowej. Obecnie (2017) jest założycielem i kierownikiem studia produkcyjnego i postprodukcyjnego Artcore, mieszczącego się w jednej z warszawskich dzielnic. To przede wszystkim dzięki Wyrzykowskiemu powstał jeden $z$ najbardziej znanych i co najważniejsze, jeden z pierwszych crowdfundingowych projektów filmowych w Polsce. Determinacja Wyrzykowskiego pozwoliła mu zrealizować coś, co na stałe zapisze się w polskiej historii. Ponad pięć lat starań dla piętnastu minut filmu z niezbyt dobrym scenariuszem, za to w jakości HD, ale było warto, choćby dla samego zrealizowania celu.

Wyrzykowski, chcąc nakręcić film, na początku nie planował, jaką drogą zbierze na niego fundusze. Liczył, że znajdzie dużego sponsora, jednak po wielu miesiącach starań okazało się, że nikt nie jest zainteresowany inwestowaniem w krótkometrażowy film nikomu nieznanego reżysera i scenarzysty (scenariusz do filmu także został stworzony przez Wyrzykowskiego). Reżyser musiał znaleźć inny sposób na zgromadzenie potrzebnej kwoty. Wpadł więc na pomysł, który był jednocześnie nieoficjalnym hasłem, jak się później okazało, całej kampanii promocyjnej filmu, a mianowicie: „Jeśli nie mogę przekonać jednej osoby, żeby dała mi dużo pieniędzy, to przekonam dużo osób, żeby dały mi trochę pieniędzy" [Wyrzykowski, 2011]. Stworzył stronę internetową o nazwie wszystko.net, na której opisał to, co chce zrobić, licząc, że stronę tę najpierw będą przekazywać sobie jego znajomi, a następnie trafi do szerszego grona odbiorców. Nie był świadomy, że to właśnie internet, który w 2006 roku, czyli w roku powstania wspomnianej strony, dopiero raczkował, jeśli chodzi o portale społecznościowe, okaże się strzałem w dziesiątkę w tym projekcie. Dzięki założonej stronie zaczęły wpływać pierwsze małe kwoty, głównie od znajomych i przyjaciół. Wyrzykowski obiecał, że każdy darczyńca, który wpłaci minimum 10 zł, będzie uwzględniony w napisach końcowych filmu oraz wypisany na stronie wszystko.net, otrzyma także DVD z filmem po jego ukończeniu. Przełomowym momentem okazał się dzień, w którym Polski Instytut Sztuki Filmowej (PISF) opublikował na swojej stronie internetowej krótką informację o projekcie. Od tego momentu Wyrzykowski 
przestał być anonimowy i mógł powołać się na wsparcie ważnej instytucji związanej z filmem. Postanowił też, że nie będzie jedynie wysyłał próśb o patronaty medialne, lecz sam zacznie umawiać się na spotkania z osobami decyzyjnymi w danej instytucji medialnej, by opowiedzieć im o projekcie i poprosić o zamieszczenie na stronie internetowej notek prasowych oraz o możliwość umieszczenia logotypu danej instytucji pod informacjami o przedsięwzięciu na stronie wszystko.net. Po czterech miesiącach od rozpoczęcia akcji reżyser i pomysłodawca miał już na koncie filmu 5 tys. zł. Wiedział jednak, że nie jest to wystarczająca kwota, więc udał się do ówczesnej dyrekcji PISF-u, prosząc o wsparcie. Na początku otrzymał patronat honorowy instytucji, a po kilku miesiącach został laureatem nagrody PISF-u, która wynosiła 20 tys. zł. Wtedy zrozumiał, że może rozpocząć gromadzenie ekipy, obsady i rozpoczać zdjęcia. Zanim jednak to zrobił, postanowił rozkręcić „burzę medialną” wokół swojego projektu, a z racji tego, że nikt wcześniej przed nim nie podjął się takiego przedsięwzięcia, media nie kryły zainteresowania. Dziesiątki wywiadów, relacji, notek prasowych, reportaży towarzyszyło autorowi i jego ekipie do zakończenia zdjęć. Wszyscy chcieli pomóc młodemu zdolnemu twórcy, jak sam określał siebie reżyser [Wyrzykowski, 2011]. W czasie czterech głównych dni zdjęciowych w maju 2007 roku dzięki promocji w mediach na konto filmu wpłynęły 4 tys. zł. Mniej więcej przez miesiąc „burza medialna” nie ustawała. Wyrzykowski szczególnie pilnował, by w czasie wywiadów telewizyjnych na ekranie telewizorów ukazywała się tzw. belka z podaną nazwą strony wszystko.net, aby ludzie łatwiej mogli na nią trafić i być może wpłacić kolejne pieniądze na film. Po zakończeniu zdjęć nastąpił pięciomiesięczny okres postprodukcji, w czasie której twórcy wydali wszystkie zgromadzone dotychczas fundusze, lecz film nadal nie był całkowicie ukończony. Szum medialny ustał, PISF zaczął pytać o produkcję, której był patronem honorowym i na którą wyłożył 20 tys. zł, internauci, którzy zainwestowali w projekt, zaczęli upominać się o obiecaną płytę. Choć film nie był w pełni ukończony pod względem technicznym, reżyser musiał pokazać go publicznie. Stało się to w marcu 2008 roku na specjalnej konferencji PISF-u. $\mathrm{Na}$ koncie filmu było wtedy 5 tys. zł zebranych od internautów w ciągu niemal roku, który upłynął od zakończenia zdjęć. Wyrzykowski wiedział jednak, że musi ukończyć film w postaci takiej, jaką sobie wymarzył i jaką obiecał swoim widzom, i że w związku z tym musi zebrać brakującą kwotę. Zrozumiał też, że możliwości internetu i internautów skończyły się na kwocie niemal 30 tys. zł zebranej od momentu powstania strony wszystko.net. Teraz przyszedł czas na środki pozyskane inną drogą. Pożyczył brakującą sumę i w kwietniu 2009 roku ukończył swój wymarzony film, którego budżet zamknął się w kwocie 80 tys. zł [Wyrzykowski, 2011].

Można by pomyśleć, że tu kończy się historia młodego twórcy, który spełnił swoje marzenie. Nic bardziej mylnego. Wciąż pozostawała kwestia premiery filmu z prawdziwego zdarzenia. W końcu odbyła się ona w lipcu 2009 roku w warszawskim kinie Muranów, a na trzech następujących po sobie seansach pojawiło się ok. 500 osób. Po raz kolejny media zaczęły interesować się filmem i jego twórcą i po raz kolejny zrobiło się o nim głośno. Po premierze Wyrzykowski 
podjął następne wyzwanie, jakim była projekcja filmu w kinach. Wykorzystał do tego inną nowatorską, jak na tamten czas, technikę - crowdsourcing. Założył więc stronę internetową o nazwie „Chcę zobaczyć Wszystko”, na której nie prosił już internautów o wsparcie finansowe, lecz pytał, czy chcieliby zobaczyć jego film oraz ile są w stanie zapłacić za bilet na niego. W sumie ok. 10 tys. osób zadeklarowało przez tę stronę, że chce zobaczyć film. Te dane Wyrzykowski pokazywał dystrybutorom filmowym oraz właścicielom kin, aby zachęcić ich do pokazania filmu, jednak nikt nie chciał się zgodzić na udostępnienie w kinach krótkometrażowego projektu. Trwało to do grudnia 2010 roku, kiedy to na rynku pojawił się nowy dystrybutor, który w końcu się zgodził. W kwietniu 2011 roku film Wszystko na 22 kopiach wszedł do kin jako dodatek do szwedzkiej produkcji, której dystrybutorem była owa chętna do współpracy firma. Po raz kolejny media zaczęły interesować się filmem i jego twórcami, a na obie strony Wyrzykowskiego dziennie wchodziło kilkadziesiąt tysięcy internautów. Szczęśliwy dla niego stał się także dobór aktorów, ponieważ w czasie premiery ich twarze były już rozpoznawalne wśród polskiej publiczności i owa rozpoznawalność także przyczyniła się do wzrostu zainteresowania samym filmem, który był dystrybuowany do sierpnia 2011 roku. Niestety zobaczyło go tylko tysiąc osób z dziesięciu tysięcy zadeklarowanych. Internauci, którzy wsparli projekt, cały czas czekali także na obiecaną płytę DVD z filmem, a było to niemal 700 osób [Wyrzykowski, 2011].

Cały projekt piętnastominutowego filmu Wszystko zamyka się w 60 miesiącach pracy. Twórcy nie otrzymali za niego wynagrodzenia, ponieważ od początku przyjęli założenie, że będzie to projekt o charakterze non profit. Czy więc opłacało się robić film tylko po to, aby był on pierwszym w Polsce krótkometrażowym filmem finansowanym przez internautów? Artur Wyrzykowski mówi, że tak, choć kosztowało go to wiele wysiłku i nie mniej pracy. Po niedługim czasie wydał film na płycie DVD i rozpoczął rozsyłanie do darczyńców. Dziś Wszystko w serwisie YouTube obejrzało już prawie 290 tys. widzów [Wszystko..., 2012].

DVD jest wzbogacone w zwiastun filmu, making-off, dodatkowy film z komentarzem twórców, zdjęcia próbne, porównanie scenorysu z filmem, sceny usunięte, fotostory i wiele innych. Szczególne znaczenie ma to, że na DVD Artur Wyrzykowski sam wyczytuje nazwiska wszystkich 700 osób, które wpłaciły swoje pieniądze na jego przedsięwzięcie.

\section{Rola przywódcy na przykładzie projektu Wszystko}

Znając całą historię, można skupić się na elementach, które przyczyniły się do tego, że projekt się udał. Oczywiście nie należy zapominać o tym, że jedynie $35 \%$ filmu zostało sfinansowane przez internautów, lecz gdyby nie ta forma promocji i nie ten zamysł projektowy, być może Wyrzykowski nie zebrałby w ogó-

le żadnej kwoty na film, nie dostałby wparcia Państwowego Instytutu Sztuki Filmowej, a media by o nim milczały. Prawdopodobnie tak właśnie by się stało, 
szczególnie że, co sam wielokrotnie powtarzał, scenariusz był kiepski. Warto również podkreślić, że wykorzystanie crowdsourcingu przy aktywizacji społeczeństwa $\mathrm{w}$ sprawie prezentacji filmu w kinach $\mathrm{z}$ jednej strony przyczyniło się do zainteresowania przedsięwzięciem, a z drugiej świadczy o nietuzinkowej postawie jego inicjatora.

Przedstawiona historia niewątpliwie pokazuje dużą determinację tylko jednej osoby, na plan pierwszy wysuwa się postać lidera, którym był Artur Wyrzykowski. Przywódca/lider to osoba, która ma dwa zadania: wprowadzać w życie to, co zaplanowała, czyli wybrać niezmienny cel i się go trzymać, oraz być w stałym i dobrym kontakcie z osobami, które pomagają jej ten cel osiągnąc [Armstrong, 1997]. Obydwa zadania z nadwyżką spełnił Wyrzykowski. Po pierwsze miał pomysł na to, co chce zrobić, niezmienny i nienaruszalny cel w postaci wyprodukowania krótkometrażowego filmu w taki sposób, w jaki robi się wielkie kasowe produkcje. Cel został osiągnięty. Po drugie Wyrzykowski utworzył wokół siebie społeczność, która mu ufała, szanowała go, lubiła i chciała z nim współpracować, chciała przyczynić się do jego sukcesu.

Na pewno ważną cechą Artura Wyrzykowskiego jest jego charyzma i umiejętność opowiadania o tym, co chce zrobić, bez przesadnej profesjonalizacji wypowiedzi, prostym, zrozumiałym dla wszystkich językiem. Obecnie jest to już mężczyzna, z pokolenia dzisiejszych trzydziestolatków, szef dobrze prosperującej firmy produkcyjnej i postprodukcyjnej, który do dnia dzisiejszego wygląda jak licealista. Niektórym może przeszkadzać jego sportowy styl ubioru, lecz on się tym nie przejmuje, robi to, co kocha, i nadal spełnia swoje marzenia. Jest to w tym kontekście bardzo ważne, ponieważ być może właśnie ten jego styl, ten wygląd człowieka, który jest sobą, nikogo nie udaje, nie przebiera się, nie jest zmanierowany, sprawił, że Wyrzykowski zyskiwał zaufanie internautów, którzy podświadomie czuli, że to chłopak taki jak oni, oraz zaufanie partnerów takich jak PISF, a także mediów - ponieważ był młody, niedoświadczony i przede wszystkim szczery w tym, co robił i mówił.

On sam podkreśla młodość jako jeden z elementów, dzięki którym udało mu się zrealizować swój projekt:

W liceum czułem już, że chcę robić filmy. Do Łodzi się nie dostałem, ale poszedłem do szkoły Ślesickiego i Lindy, byłem tam pierwszym rocznikiem. Nie miałem pieniędzy, ale Ślesicki dał mi stypendium. Nie skończyłem tej szkoły, bo chciałem zrobić film Wszystko na taśmie, a szkoła dawała inne warunki. Potem poszedłem na produkcję do Łodzi, lecz też zrezygnowałem, bo stwierdziłem, że szkoła nie nauczy mnie nic więcej, niż sam się nauczę przy produkcji mojego filmu [Wyrzykowski, 2013, materiały własne autorek].

Może się wydawać, że przemawiała przez niego pycha, lecz wtedy naprawdę $\mathrm{w}$ to wierzył i w dużej mierze miał rację, choć po czasie sam przyznał, że była to bardzo ryzykowna decyzja, ponieważ aby ukończyć film, musiał założyć własną firmę, dzięki której miał zarobić brakującą kwotę na ów projekt, co początkowo okazało się wielką pomyłką. 
Założyliśmy z przyjaciółmi Artcore, żeby sfinansować do końca film Wszystko. Jednak nie wiedzieliśmy, na co się piszemy. Nigdy wcześniej nie pracowałem w żadnej firmie, nie miałem doświadczenia w zarządzaniu, więc popełniłem wszystkie możliwe błędy, jeśli chodzi o prowadzenie własnej działalności. Otarliśmy się nawet o bankructwo, ale przetrwaliśmy. Na własnej skórze przekonałem się, jak trudne jest zarabianie pieniędzy [Wyrzykowski, 2013, materiały autorek].

Drugim ważnym elementem, który przyczynił się do powodzenia projektu, było to, że twórcom towarzyszyło wielkie szczęście niemal przez cały czas trwania przedsięwzięcia.

Obok niekwestionowanego lidera warto wyróżnić również znakomity i nowatorski pomysł na projekt. Filmów krótkometrażowych jest wiele, to jednak był pierwszy film finansowany przez internautów, i to w okresie, w którym sam internet w Polsce dopiero ewoluował, a portale społecznościowe ledwie zaczynały się popularyzować. Warto przytoczyć jeszcze raz hasło, które towarzyszyło Arturowi Wyrzykowskiemu przez cały czas realizowania produkcji, a mianowicie: „Jeśli nie mogę przekonać jednej osoby, żeby dała mi dużo pieniędzy, to przekonam dużo osób, żeby dały mi trochę pieniędzy" [Wyrzykowski, 2011]. Od pomysłu do realizacji w tym przypadku była dość krótka droga, powstała strona wszystko.net. W dzisiejszych czasach Wyrzykowski zapewne utworzyłby wydarzenie na portalu społecznościowym, jednak wtedy musiał działać inaczej. Powstanie strony stworzyło miejsce, gdzie Wyrzykowski mógł napisać wszystko o swoim pomyśle, filmie, zdawać relacje z przebiegu prac i z realizacji projektu. Już nie tylko mówił, że chce zrobić film - miał stronę internetową, która mogła reprezentować jego idee. Ponadto fundusze, które zbierał na film, trafiały nie do rąk prywatnych, ale do stowarzyszenia związanego z animacją kultury. Wyrzykowski miał więc za sobą nie tylko profesjonalną stronę, ale też organizację z podstawą prawną. Zdawał sobie sprawę, że to dopiero początek, wiedział, że aby zdobyć zaufanie internautów, musi mieć silnego partnera, który to zaufanie już zdobył. Takim partnerem okazał się właśnie Państwowy Instytut Sztuki Filmowej. Notki o projekcie, nagroda przekazana przez Instytut, ale przede wszystkim możliwość używania jego logotypu sprawiły, że ludzie niemal masowo zaczęli wpłacać swoje pieniądze na film.

Następną ważną kwestią było osobiste udawanie się do przedstawicieli różnych firm i mediów z prośbą o wsparcie finansowe, partnerskie lub medialne. To, że Wyrzykowski nie wysyłał tylko zwykłych notek, ale sam osobiście stawiał się na rozmowę i opowiadał o swoim pomyśle, miało niebagatelne znaczenie dla powstania szumu medialnego wokół filmu. Kolejnym krokiem było zatrudnienie aktorów młodego pokolenia do wzięcia udziału w projekcie. Udało mu się zwerbować znanego z Dnia świra Michała Koterskiego oraz Antoniego Pawlickiego, rozpoczynającego karierę aktorską po głośnym filmie $Z$ odzysku, w którym grał główną rolę. W tym czasie Marta Żmuda-Trzebiatowska także stała się znana, więc Wyrzykowski mógł promować swój film, mówiąc, że grają w nim gwiazdy młodego pokolenia. Innym elementem przyczyniającym się do wzrostu ruchu na stronie projektu było obowiązkowe umieszczanie „,belki” z jej nazwą w mediach 
audiowizualnych $\mathrm{w}$ czasie relacji z planu filmowego lub pokazywania wywiadów z twórcami, o co szczególnie dbał sam pomysłodawca przedsięwzięcia.

Niewątpliwie samozaparcie młodego twórcy przyczyniło się do sukcesu projektu. Nie spoczął na laurach po nakręceniu filmu, lecz chciał swój pomysł zrealizować w stu procentach, czyli zorganizować uroczystą premierę i wprowadzić swą produkcję do kin. Wszystko to mu się udało. Zapewne obietnica wysłania każdemu darczyńcy płyty DVD była dodatkowym bodźcem przyczyniającym się do tego, że ludzie chętniej wpłacali pieniądze, ponadto świadomość, że ich nazwisko znajdzie się w napisach końcowych jakiegokolwiek filmu, była jeszcze większym motywatorem.

Istnieje pięć zasad skutecznego crowdfundingu, a mianowicie: zebranie wokół projektu pewnej oddanej grupy ludzi, ustalenie koncepcji, schematu wykonywanych czynności, zaangażowanie i informowanie społeczności o wszelkich nowościach w projekcie na bieżąco, skonstruowanie pełnego opowiadania o projekcie z uwzględnieniem materiałów audiowizualnych dotyczących przedsięwzięcia, by zaprezentować jego twórców, oraz przygotowanie wyjątkowych nagród dla darczyńców [5 zasad..., 2014]. Lider filmu Wszystko spełnił każdy z tych warunków, choć według niego wcale nie miał ustalonego planu promocji projektu [Wyrzykowski, 2011]. Jednak nawet w sposób nieuświadomiony udało mu się wypromować i zrealizować swoje marzenie.

Dziś Artur Wyrzykowski mówi, że po raz drugi tak wielkie przedsięwzięcie nie udałoby się ani jemu, ani komukolwiek innemu, ponieważ działania społecznościowe nie są już niczym nowym, a ogólnopolskie media nie zrobiłyby masowego szumu wokół podobnych przedsięwzięć. Palmę pierwszeństwa i zainteresowania nowością zdobył już Wyrzykowski i jego film Wszystko.

\section{Podsumowanie}

W tym miejscu pada ostatni klaps historii o tym, że nie można się poddawać i warto spełniać marzenia, nawet wtedy, kiedy jest się w danej dziedzinie pionierem, przecierającym nieodkryte dotąd szlaki, a przez niektórych ludzi uważanym za szaleńca. Historia Artura Wyrzykowskiego pokazuje jednak, że jeżeli robi się coś $\mathrm{z}$ pasją, wkłada się w to cały swój talent i jest się przy tym szczerym i uczciwym względem siebie, współpracowników oraz widzów - to przedsięwzięcie z pewnością się uda.

Artykuł pokazuje przykład innowacyjnego podejścia do tematu crowdfundingu i crowdsourcingu w sferze kultury oraz niebagatelną rolę przywódcy w omawianym przypadku. Powszechnie znane są międzynarodowe projekty tego typu, tu jednak istotne jest, że to pierwsza taka inicjatywa w Polsce, a przy tym historia jak z filmu i dotycząca właśnie filmowca. Wspólnota, jaką dają narzędzia społecznościowe, pozwala stworzyć rzeczy i dzieła unikatowe, bazujące przy okazji na poczuciu wzajemnych celów i dążeń. Czy może zatem istnieć coś piękniejszego? 


\section{Bibliografia}

5 zasad skutecznego crowdfundingu (2014), Forbes, https://www.forbes.pl/pierwszy-milion/5-zasad-skutecznego-crowdfundingu/3temzyj [dostęp: 15.10.2017].

Armstrong M. (1997), Jak być lepszym menedżerem, [tłum. P.M. Zwoliński, P. Turnau], Dom Wydawniczy ABC, Warszawa.

Brożek B. (2014), Granice interpretacji, Copernicus Center Press, Kraków.

Kostera M. (2003), Antropologia organizacji. Metodologia badań terenowych, Wydawnictwo Naukowe PWN, Warszawa.

Wszystko - pierwszy polski film finansowany przez internautów (2012), YouTube, https:// www.youtube.com/watch?v=FRL16wvIoMs [dostęp: 15.10.2017].

Wyrzykowski A. (2011), Crowdsourcing, jako metoda zdobywania środków na realizacje filmów, materiał audiowizualny należący do Filmteractive, YouTube, https://www.youtube. com/watch? v=mbgBpGhZsAM [dostęp: 14.10.2017]. 